\title{
ICE CREAM WITH ORGANIC KAVILCA (BUCKWHEAT) FIBRE: MICROSTRUCTURE, THERMAL, PHYSICOCHEMICAL AND SENSORY PROPERTIES
}

\author{
Mustafa Fatih Ertugay ${ }^{1}$, Filiz Yangılar $^{2 凶}$, Kadir Çebi $^{2}$ \\ ${ }^{I}$ Department of Food Engineering, Faculty of Engineering, Erzincan Binali Ylldırlm University, 24000, \\ Erzincan, Turkey \\ ${ }^{2}$ Department of Nutrition and Dietetics, Faculty of Health Sciences, Erzincan Erzincan Binali Yuldirım \\ University, 24000, Erzincan, Turkey \\ $\otimes_{f y a n g i l a r @ e r z i n c a n . e d u . t r}$ \\ https://doi.org/10.34302/crpjfst/2020.12.3.3 \\ Article history: \\ Received: \\ Accepted: \\ 28 January 2020 \\ 5 June 2020 \\ Keywords: \\ Kavlca fibre; \\ Ice cream microstructure; \\ Thermal conductivity; \\ Sensory properties

\section{ABSTRACT} \\ In this study, the effects of functionality of Kavilca fibre on ice cream \\ physicochemical and sensory characteristics were evaluated. The \\ supplemented ice cream samples were found reduced number of intercellular \\ space and diameters because of the existence of filamentous extensions \\ surrounding the protein network. According to DSC, glass transition $\left(\mathrm{Tg}_{\mathrm{g}}{ }^{\prime}\right)$, \\ freezing point $\left(\mathrm{T}_{\mathrm{f}}\right)$, melting $\left(\mathrm{T}_{\mathrm{m}}\right)$, and melting point $\left(\mathrm{T}_{\mathrm{m}}\right)$ values \\ demonsrated a significant decrease with the rising of fibre concentration. In \\ general assessment, the results have been revealed that Kavilca fibre can \\ improve the quality and sensory properties of ice cream and can be used as \\ a fat substitute.
}

\section{Introduction}

Wheat is one of the most widely used cultural plants in human nutrition throughout the world, and besides, it constitutes the basis of basic nutrients in our country and in the other developing countries. There are different varieties of wheat caused by the variations in the number of its chromosomes. In contrast to bread wheat (Triticum aestivum), which is used widely today, Triticum dicoccum variety is the wheat variety that was consumed widely until the $19^{\text {th }}$ century and is known as "Emmer", "Kavilca", and "Gernik." Kav1lca is an ancient wheat variety that has been cultivated for centuries and that is becoming extinct. It is also known as Kavilca, Kabluca, and Yaban Wheat in the Kars region of Turkey (English: Emmer, Latin: Triticum dicoccum, Italian: Ferro). This variety, one of the ancestors of wheat, has many properties that are different from those of the modern wheat varieties. Kavilca is also known as "buckwheat" (Hayıt and Gül, 2005; Bilgiçli,
2009). Buckwheat (Fagopyrum esculentum Moench.), which belongs to the family Polygonaceae, is an annual plant and it is known that it resembles grains regarding its chemical compound and usage characteristics. It consists of dietary fibre, essential polyunsaturated fatty acids (PUFAs), vitamins (B1, B2, and B6), and antioxidant compounds such as routine and quercetin, and minerals $(\mathrm{P}$, $\mathrm{K}, \mathrm{Mg}$, and $\mathrm{Fe}$ ). Because buckwheat has high nutrient quality, it has a great potential in food industry in terms of functional food production (Dizlek et al., 2009). The incorporation of buckwheat fibre which is rich in fibre content can be included in dairy technology such as ice cream industry as an ingredient to be used in the manufacture of new functional products with high nutritional value and distinct flavour and aroma.

Gluten is excluded from the diet of coeliac patients as it causes serious bowel symptoms 
(Hayit and Gül, 2005; Torbica et al., 2010). Unfortunately, their sole treatment process is seriously sticking to a diet that does not include gluten throughout their whole lives. We define a diet free of wheat, barley, and rye flour as a gluten-free diet (Ciclitira et al., 2005; Urganc1, 2005; Türksoy and Özkaya, 2006). Buckwheat is a food component that meets an ideal glutenfree diet for gluten patients since this variety of wheat does not include gluten (Hayıt and Gül, 2005; Bilgiçli, 2009). Using this wheat, can be a good substitute for the ingredients being used in gluten-free products.

In conclusion, because we thought that Kavilca, an ancient fat variety of wheat, should be kept under protection and its production should be expanded and supported by scientific studies, we produced ice cream with the fibre that we obtained in our study. We aimed to find out how it affected the quality, thermal properties, nutritional and rheological properties of ice cream, and to reveal its profile map of physical and sensorial properties such as increased in volume and melting.

\section{Materials and Methods}

\subsection{Materials}

Raw cow milk and cream were purchased from Balacan Farm landing Erzincan province, Turkey and sugar, salep, skim milk powder and emulsifier (mixture containing mono and diglycerides of fatty acids) were obtained from local markets. The organic Kavilca wheat was fetched from a local production at Hacipiri village of Akyaka district of Kars in Turkey and fibre was produced using a traditional milling machine according to the modified methods of Bauer et al. (2012).

\subsection{Physicochemical composition of dietary fibre}

Moisture and ash content were determined by the methods described in Martinez et al. (2012) and AACC (1995), respectively. The fibre $\mathrm{pH}$ was determined using a $\mathrm{pH}$ meter (OHAUS starter 3000; Vyncke, 1981). The contents of consisting of soluble dietary fibre (SDF), total dietary fibre (TDF) and insoluble dietary fibre (IDF) were found using enzymatic method (AACC, 2009).

\subsection{Ice cream samples processing}

The ice cream samples were produced in the Sofra patisserie, Erzincan, Turkey. First, fat contents of mixes were standardized to $5 \%$ by adding cream. The formulation of ice cream mix consisted of skimmed milk powder $4.7 \%$, sugar $18 \%$, a stabiliser salep; $0.6 \%$, emulsifiers $0.2 \%$ and Kavilca fibre (KF) added separately at $0.5 \%$, $1 \%, 1.5 \%$ and $2 \%$ ratios to experimental groups except control sample. The mixtures were pasteurized at $85^{\circ} \mathrm{C}$ for $20 \mathrm{~min}$ and stored at $4^{\circ} \mathrm{C}$ for $24 \mathrm{~h}$ and the mixes were frozen using an ice cream freezer (Ugur Cooling Machineries Co., Nazilli, Turkey) to the ice cream production. Later each experimental sample was packaged and stored at $-22^{\circ} \mathrm{C}$. The production and flow chart of the ice cream samples are presented in Figure 1 and 2, respectively 
a)
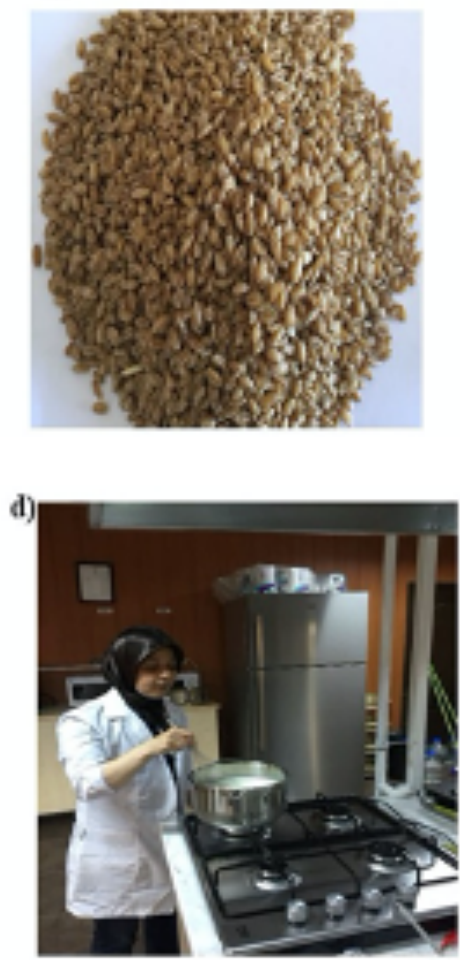

b)
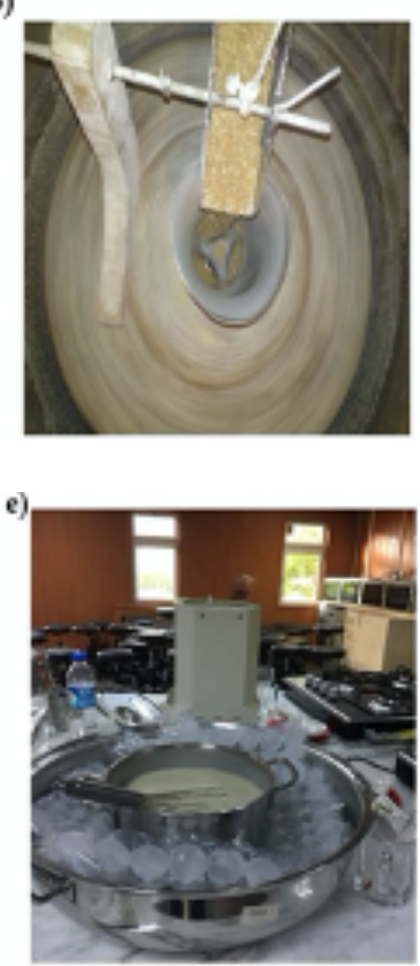

c)
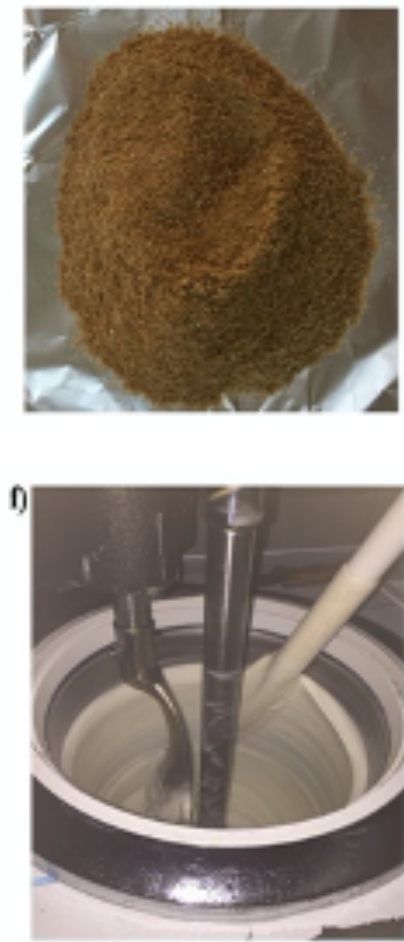

Figure 1. a) organic Kavılca wheat; b) flour was produced using a traditional milling machine; c) fibre obtained from organic Kavilca; d) production of mix; e) mix; f) production of ice cream.

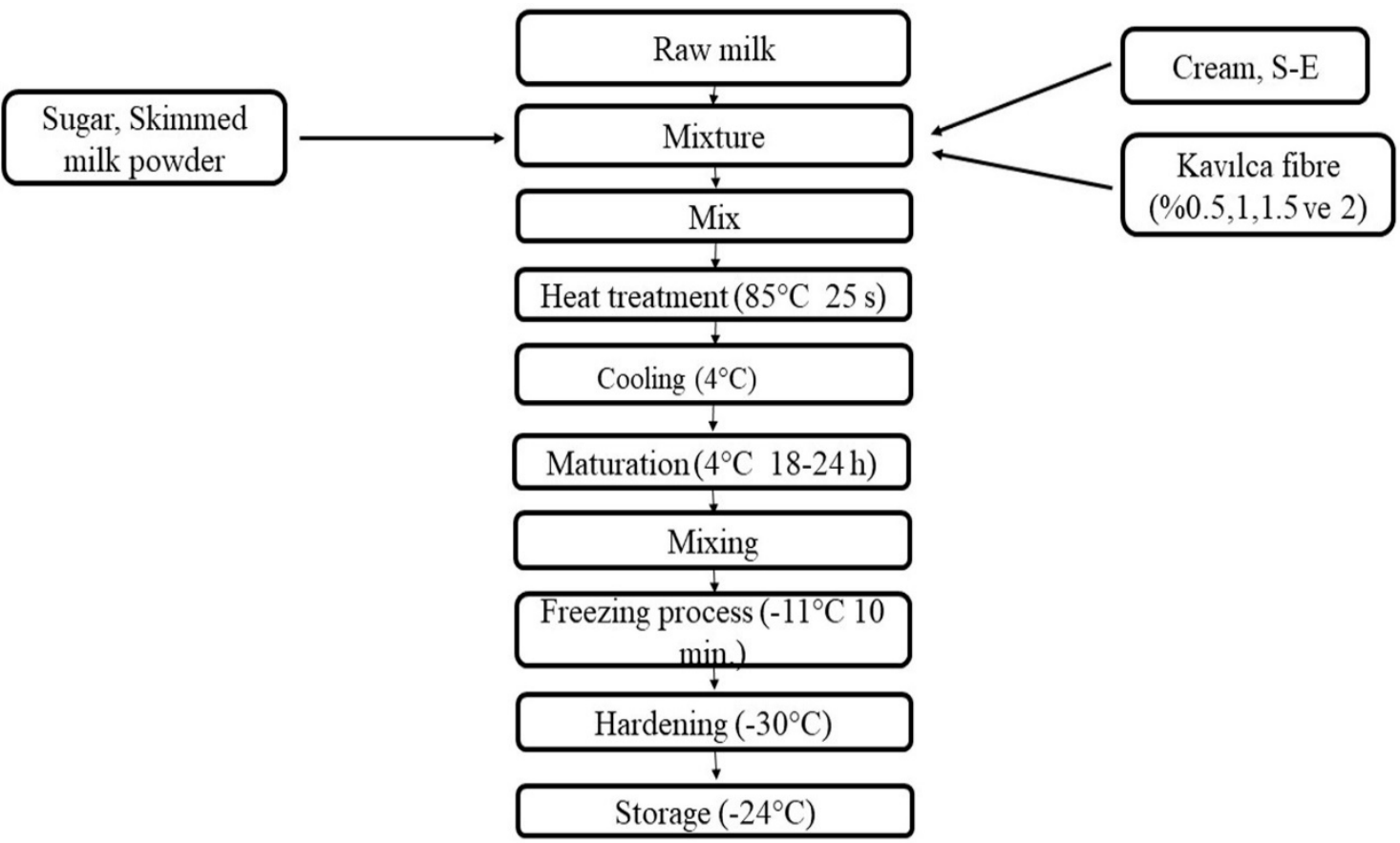

Figure 2. The flow chart of the ice cream samples 


\subsection{Physicochemical analysis of sample treatments}

The moisture, acidity, fat and ash were analyzed according to Kurt et al. (2007) method and $\mathrm{pH}$ was measured using a $\mathrm{pH}$ metre (Ohaus starter 3000). The apparent viscosity was measured using a digital Brookfield Viscometer, Model DVI (Brookfield Engineering Lab- Inc, USA; Akın et al., 2007) and overrun were determined in ice cream samples according to the Marshall and Arbuckle (1996) and Güven and Karaca (2002) methods.

\subsection{Microstructure analysis}

Microstructure analysis in ice cream samples was carried out using Scanning Electron Microscopy (SEM; FEI, Quanta FEG 450) according to the modified methods of Akalın et al. (2012). The samples were weighed aluminium tubes (inner diameter $1.16 \mathrm{~mm}$, length $30 \mathrm{~mm}$ ) as $0.3 \mathrm{~g}$ and the aluminium tube was pushed twice into the ice cream approximately $1-2 \mathrm{~cm}$ below the surface. The measurements were recorded with magnification 5000 and 30.000 at $15 \mathrm{kV}$ under low vacuum condition.

\subsection{DSC measurements}

DSC measurements of thermograms were obtained with using EXTAR DSC 7000 equipped. Aliquots (approximately $15 \mathrm{mg}$ ) of each sample were sealed into aluminium pans and then loaded onto the DSC instrument. The samples were prepared following methodology adapted from Blond (1994), and it was applied including this steps: (i) cooling to $-80{ }^{\circ} \mathrm{C}$ at 10
${ }^{\circ} \mathrm{C} / \mathrm{min}$, (ii) heating from -80 to $-40{ }^{\circ} \mathrm{C}$ and annealing at the same temperature for $30 \mathrm{~min}$ to promote maximal ice formation, (iii) cooling to $-80{ }^{\circ} \mathrm{C}$ at $10{ }^{\circ} \mathrm{C} / \mathrm{min}$ and isothermal holding for $5 \mathrm{~min}$ and (iv) heating from -80 to $20^{\circ} \mathrm{C}$ at 5 ${ }^{\circ} \mathrm{C} / \mathrm{min}$.

\subsection{Sensory evaluation}

Sensory properties were carried out in ice cream samples after 1 week of storage according to Lawless and Heymann (2010) and the evaluation was performed by 20 panelists. The 9-point hedonic scale that consisted of points between 1 (dislike extremely) and 9 (like extremely) was used for the specified sensory attributes which were resistance to melting, body and texture, cream aroma, colour, taste and aroma, mouthfeel, gumming structure, iced structure and general acceptability.

\subsection{Statistical analysis}

Statistical analysis was performed using SPSS 22.0 (IBM Corp., Released 2013). Data were analyzed by analysis of variance (ANOVA) and the differences between means by the ANOVA and Duncan's Multiple Range Test were used to determine significant differences among the results.

\section{Results and Discussion}

The chemical composition of milk is used to produce Kavilca fibre ice cream was as follows: titratable acidity $0.17 \%( \pm 0.00)$ as lactic acid (L.A.), $\mathrm{pH} 6.37$ ( \pm 0.03$)$, total solids $11.01 \%( \pm 0.01)$, fat $3.09 \%( \pm 0.00)$, protein $2.88 \%( \pm 0.02)$ and ash $0.66 \%( \pm 0.02)$.

Table 1. The gross chemical and physical properties of Kavilca fibre

\begin{tabular}{|c|c|}
\hline Analysis & Kavlca fibre \\
\hline Dry matter (\%) & $93.72 \pm 0.50$ \\
\hline $\mathrm{pH}$ & $6.44 \pm 0.01$ \\
\hline Ash (\%) & $2.94 \pm 0.00$ \\
\hline
\end{tabular}




\begin{tabular}{|c|c|}
\hline Total dietary fibre $(\mathrm{g} / 100 \mathrm{~g})$ & $50.19 \pm 0.79$ \\
\hline Insoluble dietary fibre $(\mathrm{g} / 100 \mathrm{~g})$ & $46.41 \pm 0.55$ \\
\hline Soluble dietary fibre $(\mathrm{g} / 100 \mathrm{~g})$ & $3.40 \pm 0.24$ \\
\hline
\end{tabular}

*n.d. -not determine

\subsection{Physicochemical qualities of dietary fibres}

As can be seen in Table 1, dry matter, $\mathrm{pH}$, ash, total dietary fibre, insoluble dietary fibre and soluble dietary fibre of its Kavilca fibre were found as $93.72 \pm 0.50,6.44 \pm 0.01,2.94 \pm 0.00$, $50.19 \pm 0.79,46.41 \pm 0.55$ and $3.78 \pm 0.24 \mathrm{~g} / 100 \mathrm{~g}$ respectively.

This result accords with the findings of Zhao et al. (2017) who reported that the ice cream samples with flour obtained from yacon (Smallanthus sonchifolius) total dietary fibre, insoluble dietary fibre and soluble dietary fibre contents to be 52.02, 39.99 and $4.84 \mathrm{~g} / 100 \mathrm{~g}$ respectively.

Our results are supported by the report with previous findings (Prosky et al., 1988; Y1lmaz, 2005; Yang1lar, 2015a; 2015b).

\subsection{Physicochemical of ice cream samples}

The average values of chemical analysis results of experimental ice cream samples and Duncan multiple test comparison results were presented in Table 2.

Table 2. The effect of different Kavilca fibre concentrations on some physicochemical properties of ice creams (mean $\pm \mathrm{SD})$

\begin{tabular}{|c|c|c|c|c|c|}
\hline $\begin{array}{c}\text { Ice cream } \\
\text { samples }\end{array}$ & $\begin{array}{c}\text { Total solids } \\
(\%)\end{array}$ & Fat (\%) & $\begin{array}{c}\text { Titratable } \\
\text { acidity (\%) }\end{array}$ & pH & Ash (\%) \\
\hline $\mathrm{C} 1$ & $31.95 \pm 0.24^{\mathrm{a}}$ & $5.42 \pm 0.03^{\mathrm{c}}$ & $0.16 \pm 0.00^{\mathrm{a}}$ & $6.73 \pm 0.01^{\mathrm{b}}$ & $1.43 \pm 0.07^{\mathrm{a}}$ \\
\hline $\mathrm{C} 2$ & $32.17 \pm 0.19^{\mathrm{ab}}$ & $5.36 \pm 0.09^{\mathrm{bc}}$ & $0.18 \pm 0.00^{\mathrm{a}}$ & $6.69 \pm 0.01^{\mathrm{a}}$ & $1.49 \pm 0.01^{\mathrm{ab}}$ \\
\hline $\mathrm{C} 3$ & $32.58 \pm 0.09^{\mathrm{bc}}$ & $5.17 \pm 0.04^{\mathrm{abc}}$ & $0.20 \pm 0.01^{\mathrm{ab}}$ & $6.71 \pm 0.01^{\mathrm{a}}$ & $1.51 \pm 0.06^{\mathrm{ab}}$ \\
\hline $\mathrm{C} 4$ & $32.88 \pm 0.08^{\mathrm{c}}$ & $5.12 \pm 0.24^{\mathrm{ab}}$ & $0.21 \pm 0.00^{\mathrm{cd}}$ & $6.70 \pm 0.00^{\mathrm{a}}$ & $1.57 \pm 003^{\mathrm{ab}}$ \\
\hline $\mathrm{C} 5$ & $32.95 \pm 0.26^{\mathrm{c}}$ & $4.91 \pm 0.02^{\mathrm{a}}$ & $0.23 \pm 0.01^{\mathrm{d}}$ & $6.68 \pm 0.01^{\mathrm{a}}$ & $1.62 \pm 0.01^{\mathrm{c}}$ \\
\hline
\end{tabular}

C1, control (without KF); C2, 0.5\% (w/w) KF added; C3, 1\% (w/w) KF added; C4, 1.5\% (w/w) KF added and $\mathrm{C} 5,2 \%(\mathrm{w} / \mathrm{w}) \mathrm{KF}$ added. *Means within the same column with different letters are significantly different $(\mathrm{p}<0.05)$.

According to the results of variance analysis, the ice cream samples were found to be statistically significant at $\mathrm{p}<0.01$ on the examined properties (dry matter, fat, titration acidity, $\mathrm{pH}$, and ash). In their studies in which they produced probiotic ice cream using apple, orange, oat, bamboo, and wheat fibres, Akalın et al. (2018) found that fibre contents affected dry matters of the samples positively and caused them to increase. The average values of the chemical analysis results of the experimental ice cream samples were given in Table 2. According 
to the results of the variance analysis, the ice cream samples were found to be statistically significant at $\mathrm{p}<0.01$ on the examined properties (dry matter, oil, titration acidity, $\mathrm{pH}$, and ash). When the values of dry matter and ash were compared, the samples were ordered as $\mathrm{C} 1<\mathrm{C} 2$ $<\mathrm{C} 3<\mathrm{C} 4<\mathrm{C} 5$. Parussolo et al. (2017) reported that the amounts of dry matter and ash of the ice cream samples that they produced using the flour obtained from yacon (Smallanthus sonchifolius) increased depending on the increased in concentration.

Regarding the amounts of fat in the ice cream samples, it was identified that the lowest amount of fat was in C5 coded sample (4.91\%) and the highest amount of fat was in $\mathrm{C} 1$ coded sample (5.42\%). Dervişoğlu and Yazıcı (2006) found the fat contents of the ice cream samples that they produced using different concentrations of fibres they obtained from citrus rind to be $6.73 \%$ with $0.4 \%$ concentration, $6.63 \%$ with $0.8 \%$ concentration, and $6.40 \%$ with $1.2 \%$ concentration. The results of the researchers were higher than those of us, but they also found that the ice creams that we produced using fibre caused a decrease in fat content depending on the increased in concentration just like in this study.

As shown in the Table 2, the increased in the fibre concentration statistically increased the titration acidity of the ice cream samples depending on the rate of increased $(p<0.05)$.
Çakmakçı et al. (2015) reported that the titration acidity values increased in the ice cream samples that they produced using different concentrations of oleaster flour and their studies were consistent with our results. Fluctuations were observed in the $\mathrm{pH}$ values of the ice cream samples with fibre addition; however, variations between the samples could not maintain their statistical significance. The highest $\mathrm{pH}$ value was found to be 6.73 in the $\mathrm{C} 1$ coded sample and the lowest $\mathrm{pH}$ value was 6.68 in the $\mathrm{C} 5$ coded sample. According to the results of Duncan multiple comparison tests, the samples were ordered $\mathrm{C} 1<\mathrm{C} 2<\mathrm{C} 3<\mathrm{C} 4<\mathrm{C} 5$ in terms of the amounts of ash.

\subsection{Thermal characteristics}

The effect of Kavilca fibre concentration on the melting and glass transition temperatures of the ice cream samples were given in Table 3 and the effect of Kavilca fibre on the freezing point temperature and melting point temperature of the ice cream samples were given in Table 4. It was detected that the glass transition temperature and the melting temperature decreased depending on the increased in the concentration when the data that were obtained using DSC device were examined in order to investigate the thermal properties of the ice cream samples that were enriched by using fibre in different concentrations.

Table 3. The effect of Kavilca fibre concentration on the glass transition and melting temperatures of ice creams (mean \pm SD)

\begin{tabular}{|c|c|c|c|c|c|c|}
\hline \multirow{2}{*}{$\begin{array}{l}\text { Ice } \\
\text { cream } \\
\text { samples }\end{array}$} & \multicolumn{3}{|c|}{$\begin{array}{c}\text { T' } \\
\text { (glass transition temperature) }\end{array}$} & \multicolumn{3}{c|}{$\begin{array}{c}\text { T' } \\
\text { (melting temperature) }\end{array}$} \\
\cline { 2 - 7 } & Onset $\left({ }^{\circ} \mathbf{C}\right)$ & $\begin{array}{c}\text { Midpoint } \\
\left({ }^{\circ} \mathbf{C}\right)\end{array}$ & Offset $\left({ }^{\circ} \mathbf{C}\right)$ & Onset $\left({ }^{\circ} \mathbf{C}\right)$ & Midpoint $\left({ }^{\circ} \mathbf{C}\right)$ & Offset $\left({ }^{\circ} \mathbf{C}\right)$ \\
\hline $\mathrm{C} 1$ & $-51.87 \pm 0.11^{\mathrm{b}}$ & $-46.90 \pm 0.52^{\mathrm{b}}$ & $-41.59 \pm 2.07^{\mathrm{b}}$ & $-36.60 \pm 1.68^{\mathrm{d}}$ & $-31.46 \pm 0.10^{\mathrm{d}}$ & $-27.57 \pm 0.91^{\mathrm{c}}$ \\
\hline $\mathrm{C} 2$ & $-57.44 \pm 0.00^{\mathrm{e}}$ & $-57.21 \pm 0.01^{\mathrm{d}}$ & $-53.24 \pm 0.05^{\mathrm{c}}$ & $-35.70 \pm 0.00^{\mathrm{cd}}$ & $-30.89 \pm 0.13^{\mathrm{d}}$ & $-27.62 \pm 0.02^{\mathrm{c}}$ \\
\hline $\mathrm{C} 3$ & $-56.32 \pm 0.02^{\mathrm{d}}$ & $-55.03 \pm 0.04^{\mathrm{c}}$ & $-53.22 \pm 0.31^{\mathrm{c}}$ & $-30.54 \pm 0.76^{\mathrm{b}}$ & $-29.02 \pm 0.03^{\mathrm{c}}$ & $-28.78 \pm 0.01^{\mathrm{c}}$ \\
\hline
\end{tabular}




\begin{tabular}{|c|c|c|c|c|c|c|}
\hline C4 & $-52.18 \pm 0.06^{\mathrm{c}}$ & $-46.79 \pm 0.07^{\mathrm{b}}$ & $-41.04 \pm 0.40^{\mathrm{b}}$ & $-32.21 \pm 0.68^{\mathrm{bc}}$ & $-27.80 \pm 0.28^{\mathrm{b}}$ & $-21.34 \pm 1.35^{\mathrm{b}}$ \\
\hline C5 & $-42.20 \pm 0.04^{\mathrm{a}}$ & $-41.86 \pm 0.26^{\mathrm{a}}$ & $-32.89 \pm 1.53^{\mathrm{a}}$ & $-14.76 \pm 1.73^{\mathrm{a}}$ & $-11.38 \pm 0.26^{\mathrm{a}}$ & $-11.04 \pm 0.67^{\mathrm{a}}$ \\
\hline
\end{tabular}

C1, control (without KF); C2, 0.5\% (w/w) KF added; C3, 1\% (w/w) KF added; C4, 1.5\% (w/w) KF added and $\mathrm{C} 5,2 \%(\mathrm{w} / \mathrm{w}) \mathrm{KF}$ added. *Means within the same column with different letters are significantly different $(\mathrm{p}<0.05)$.

As we can see in Table 3 , the highest $\mathrm{T}_{\mathrm{g}}{ }^{\prime}$ values were found in the sample $\mathrm{C} 5$ and the samples C1, C4, C3, and C2 followed it respectively. When the results were evaluated from a statistical point of view, the effect of fibre addition on the $T_{\mathrm{g}}{ }^{\prime}$ and $\mathrm{T}_{\mathrm{m}}{ }^{\prime}$ values of the samples were found to be significant $(\mathrm{p}<0.01)$ and decreases in glass transition and melting temperatures were detected as the fibre concentration increased. Yüksel (2015a) found that the $\mathrm{T}_{\mathrm{g}}{ }^{\prime}$ and $\mathrm{T}_{\mathrm{m}}{ }^{\prime}$ values of the ice cream samples he produced using different concentrations of blackthorn (Prunus spinosa) were parallel to our results. The researcher commented that the decrease in $\mathrm{T}_{\mathrm{g}}{ }^{\prime}$ and $\mathrm{T}_{\mathrm{m}}{ }^{\prime}$ values could be due to the fact that the water content in the ice cream samples had been frozen. Our study results are consistent with the results of the DSC analysis of the ice cream samples that Soukoulis et al. (2009) produced using wheat fibre.

Table 4. The effect of Kavilca fibre concentration on the freezing point temperature and elting point temperature of ice creams (mean \pm SD)

\begin{tabular}{|c|c|c|c|c|}
\hline $\begin{array}{c}\text { Ice cream } \\
\text { samples }\end{array}$ & $\begin{array}{c}\text { Initial } \\
\text { freezing point } \\
\mathbf{T}_{\mathbf{f}}\left({ }^{\circ} \mathbf{C}\right)\end{array}$ & $\begin{array}{c}\text { Heat of ice freezing } \\
\text { (enthalpy) } \Delta \mathbf{H}(\mathbf{J} / \mathbf{g})\end{array}$ & $\begin{array}{c}\text { Initial melting } \\
\text { point } \mathbf{T}_{\mathbf{m}}\left({ }^{\circ} \mathbf{C}\right)\end{array}$ & $\begin{array}{c}\text { Heat of ice } \\
\text { melting } \\
(\mathbf{e n t h a l p y )} \Delta \mathbf{H} \\
(\mathbf{J} / \mathbf{g})\end{array}$ \\
\hline $\mathrm{C} 1$ & $-12.42 \pm 0.65^{\mathrm{b}}$ & $128 \pm 16.97^{\mathrm{bc}}$ & $-2.10 \pm 0.43^{\mathrm{a}}$ & $109 \pm 15.55^{\mathrm{a}}$ \\
\hline $\mathrm{C} 2$ & $-10.53 \pm 0.04^{\mathrm{a}}$ & $124 \pm 1.41^{\mathrm{ab}}$ & $-3.02 \pm 0.03^{\mathrm{b}}$ & $117 \pm 2.82^{\mathrm{a}}$ \\
\hline $\mathrm{C} 3$ & $-14.50 \pm 0.00^{\mathrm{d}}$ & $145.50 \pm 0.70^{\mathrm{c}}$ & $-2.40 \pm 0.14^{\mathrm{ab}}$ & $94.20 \pm 1.13^{\mathrm{a}}$ \\
\hline $\mathrm{C} 4$ & $-13.43 \pm 0.51^{\mathrm{cd}}$ & $138.5 \pm 2.12^{\mathrm{bc}}$ & $-2.59 \pm 0.06^{\mathrm{ab}}$ & $101.50 \pm 2.12^{\mathrm{a}}$ \\
\hline $\mathrm{C} 5$ & $-10.60 \pm 0.77^{\mathrm{a}}$ & $104.5 \pm 0.70^{\mathrm{a}}$ & $-2.36 \pm 0.44^{\mathrm{ab}}$ & $100.65 \pm 4.73^{\mathrm{a}}$ \\
\hline
\end{tabular}

C1, control (without KF); C2, 0.5\% (w/w) KF added; C3, 1\% (w/w) KF added; C4, 1.5\% (w/w) KF added and $\mathrm{C} 5,2 \%(\mathrm{w} / \mathrm{w}) \mathrm{KF}$ added. *Means within the same column with different letters are significantly different $(\mathrm{p}<0.05)$.

In Table 4, the highest $\mathrm{T}_{\mathrm{f}}$ value was found in the sample $\mathrm{C} 2$ and the lowest in the sample $\mathrm{C} 3$; and the highest $\mathrm{T}_{\mathrm{m}}$ value was found in the $\mathrm{C} 1$ and the lowest in the sample C2. The freezing point and the melting point temperatures of the ice cream samples were found statistically significant $(\mathrm{p}<0.01)$. The results show that the density and composition of fibre might have affected the molecular water of the ice cream.

\subsection{Microstructure}

Identification of microstructures of foods is important in terms of dimensional regulation of identifiable components that constitute the food, understanding of their interaction with each other, and providing information about their 
physical conditions. When we examine a product such as ice cream from a technological point of view, we need to emphasize that the microstructure of a product is important in order to realize a production with the desired textural and sensory properties. The microstructures of the fibre and ice cream samples that were obtained using Scanning Electron Microscope (SEM) are seen in Figure 3. We determined that the microstructure of the fibre was distributed in the gel homogeneously. Sánchez-Alonso et al. (2006) also detected a result of the microstructure of a similar wheat fibre. When we examine the shapes of the ice cream samples, it is obvious that there are significant structural variations between the control sample and the samples containing Kavilca fibre. We also see the result that there are more serum phases and gaps in the control sample in the control groups of the studies conducted by Sandoval-Castilla et al. (2004) and Ramirez-Santiago et al. (2010). However, it was determined that filamentous extensions and serum phases existed in the samples that Kavilca fibre was added into, but the number of gaps and their diameters decreased.
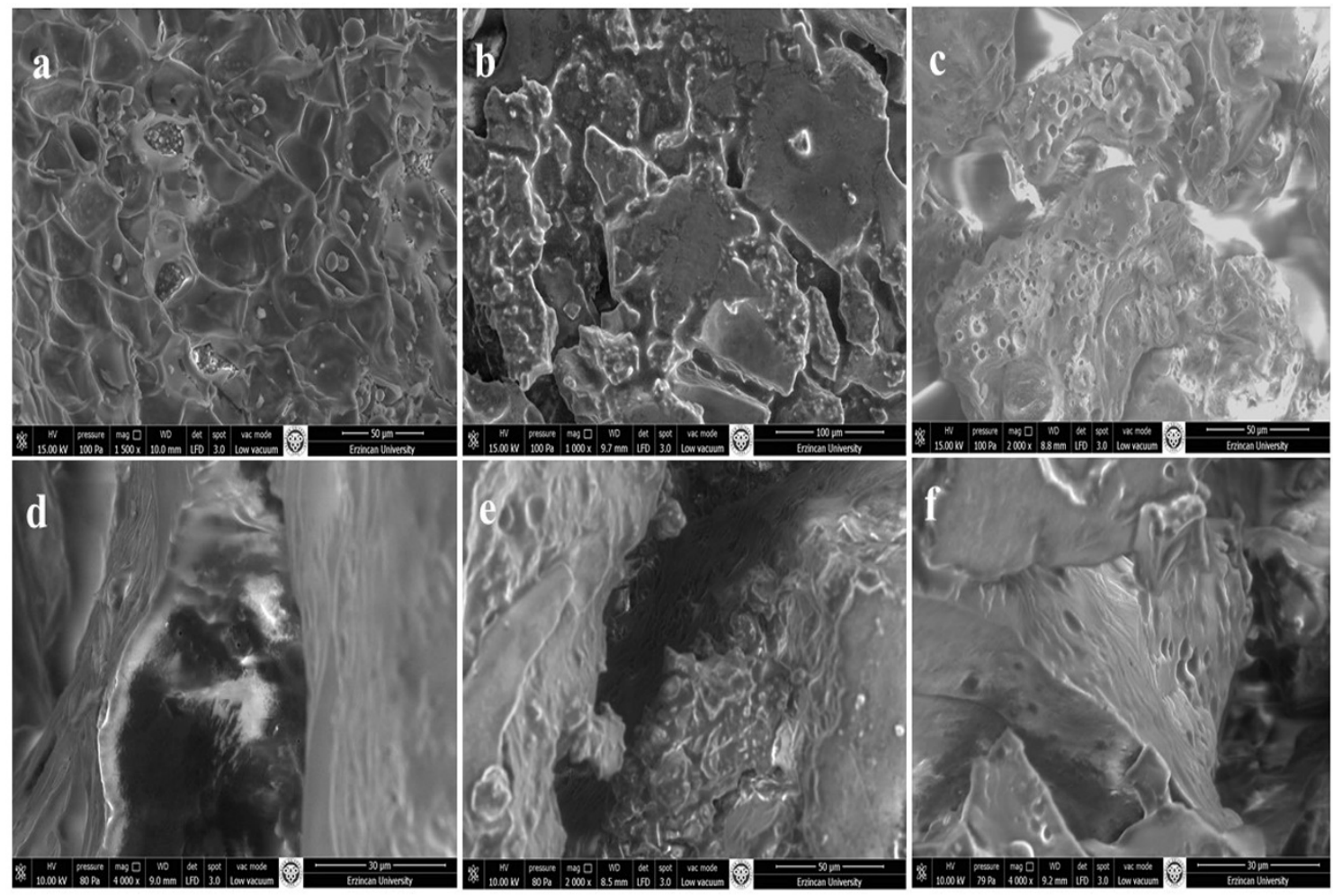

Figure 3. Scanning electron micrographs of ice cream samples and fibre. Labelled arrows: a. fibre; b. control; c. $0.5 \%(\mathrm{w} / \mathrm{w})$ Kavilca fibre added; d. $1 \%(\mathrm{w} / \mathrm{w})$ Kavilca fibre added, e. $1.5 \%(\mathrm{w} / \mathrm{w}) \mathrm{Kav} 1 \mathrm{lca}$ fibre added, f. $2 \%(\mathrm{w} / \mathrm{w})$ Kavilca fibre added.

In their studies, Soukoulis et al. (2009) reported that the samples with oat and wheat fibres affected viscosity significantly among the ice cream samples that they produced using apple, oat, wheat fibres and inulin, and a tougher structure was formed; and they reported that this was probably because of undissolved materials bound the water. They also reported that the serum phase of the microstructures of the samples containing $4 \%$ oat and wheat fibres decreased by means of the fibres that held the water and this caused an increased in viscosity. They detected that the fibres that were comprised of polysaccharides contributed to the effect of apple fibre on viscosity and viscosity increased 3-15 times the control sample. The 
researchers reported that the fact that ice creams with apple fibre do not have granular structures, but they contain much pectin had a positive effect on viscosity in consequence of the examination of their microstructures. They already reported in their previous studies that pectin was an anionic hydrocolloid that could interact with positive charges on protein surface (Soukoulis et al. 2007).

Akalın et al. (2018) produced probiotic ice cream using different dietary fibres (apple, orange, oat, bamboo, and wheat) and investigated their microstructures. When they compared the ice cream samples that were produced using serum phase of the control samples and dietary fibre, they found that it was more watery and they reported that only the sample with wheat fibre was effective on the increased in viscosity $(\mathrm{p}<0.05)$. They reported that apple and orange fibre added ice cream samples were different from the ice creams that were produced using bamboo, oat, and wheat fibre in terms of granular structure. However, they found that a significant increased occurred in viscosity in also the samples produced using apple and orange fibre $(\mathrm{p}<0.05)$.

\subsection{Viscosity analysis}

The data on the results of viscosity analysis of the experimental ice cream samples were given in Figure 4. Regarding the values that were obtained at 20 and $50 \mathrm{rpm}$, it was observed that the sample C5 had the highest viscosity value, and the group $\mathrm{C} 1$ (control group) had the lowest.

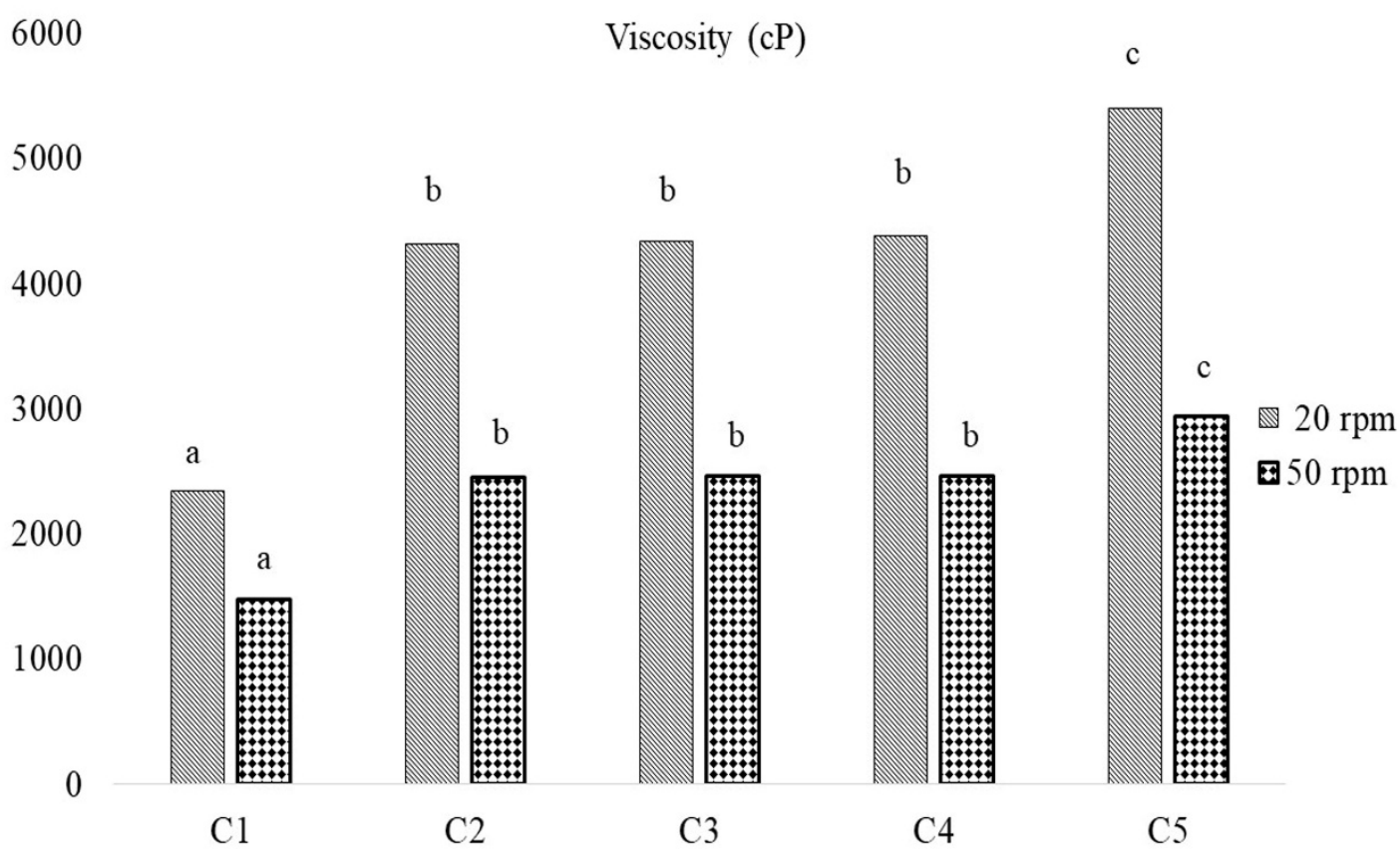

Figure 4. Viscosity values of ice cream mixes. Different letters above the bars indicate significant differences by Duncan multiple range test $(\mathrm{p}<0.05)$.

In their studies in which they produced probiotic ice cream using apple, orange, oat, bamboo, and wheat fibres, Akalın et al. (2018) reported that the effects of fibre contents on the viscosity of the samples were $0.133,0.120$, $0.082,0.071,0.043$, and 0.042 for apple, orange, wheat, bamboo, oat, and control samples, respectively. They stated that the fact that wheat 
fibre provided the samples a higher viscosity than oat fibre did was because of different fibre compositions and the dissolution rate and the rate of insolubles as Alan et al. (2012) also stated. Rodehutscord et al. (2016) reported that wheat fibre had a higher viscosity when compared with oat fibre.

\subsection{Overrun analysis}

The average values of the increased in the volume of the samples were presented and arranged in Figure 5 for better comprehension. All the samples were found statistically different from one another in terms of increased in volume.

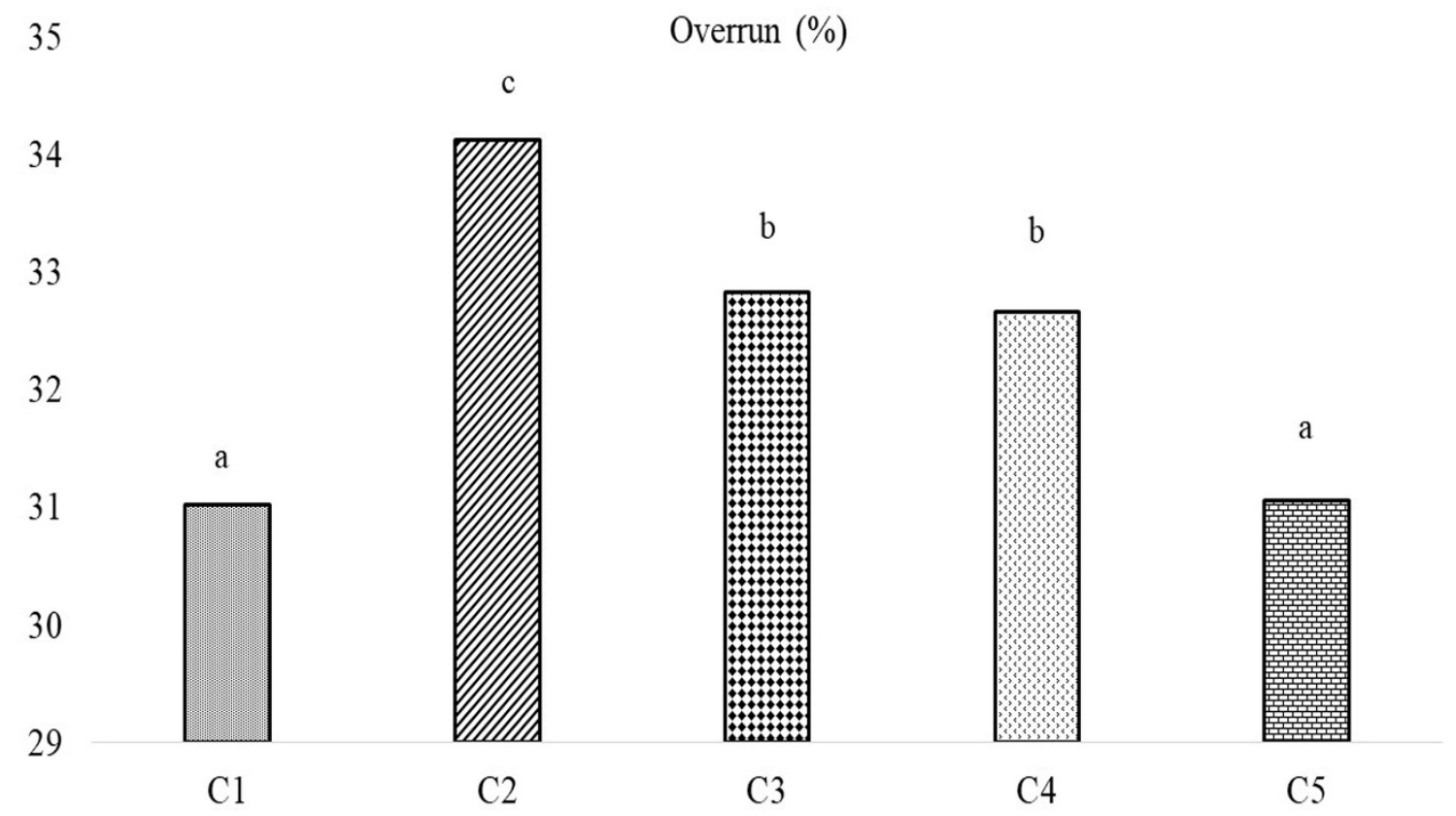

Figure 5. Overrun values of ice cream samples. Different letters above the bars indicate significant differences by Duncan multiple range test $(p<0.05)$

Crizel et al. (2014) reported that the increased in the volume of the samples they produced adding orange fibre in addition to different formulations were lower than those of the control sample and this might be because of the decrease in the fat content of the samples. It was reported that the decrease in volume increased caused the control groups to have a higher melting rate and this was caused by the air cells that exist in the structure of ice cream (Marshall et al., 2003). A study that confirms this finding was conducted by Akalin et al. (2018). The researchers detected that the ice creams that they produced using wheat fibre had lower melting rate than that of the control group throughout the storage period. They also found that the sample with wheat fibre exhibited a lower melting rate than those of the samples with bamboo and oat fibre throughout the storage period. They stated that it might be because wheat fibre provided the ice cream samples a tougher structure. 


\subsection{First dripping and complete melting times}

As can be seen in Figure 6, times of first drop and full melting were found the earliest in the $\mathrm{C} 1$ coded sample and the latest in the C5 coded sample. There are some factors that are effective on the rates of melting of ice creams. The diffusion of heat into the ice cream samples emerges as a reason. The high rate of increased in volume decreases the melting rates because of the diffusion of heat. Fat molecule clusters that exist in the air gaps in the ice creams and their aggregations are effective on the melting of ice creams (Akbari et al., 2016).

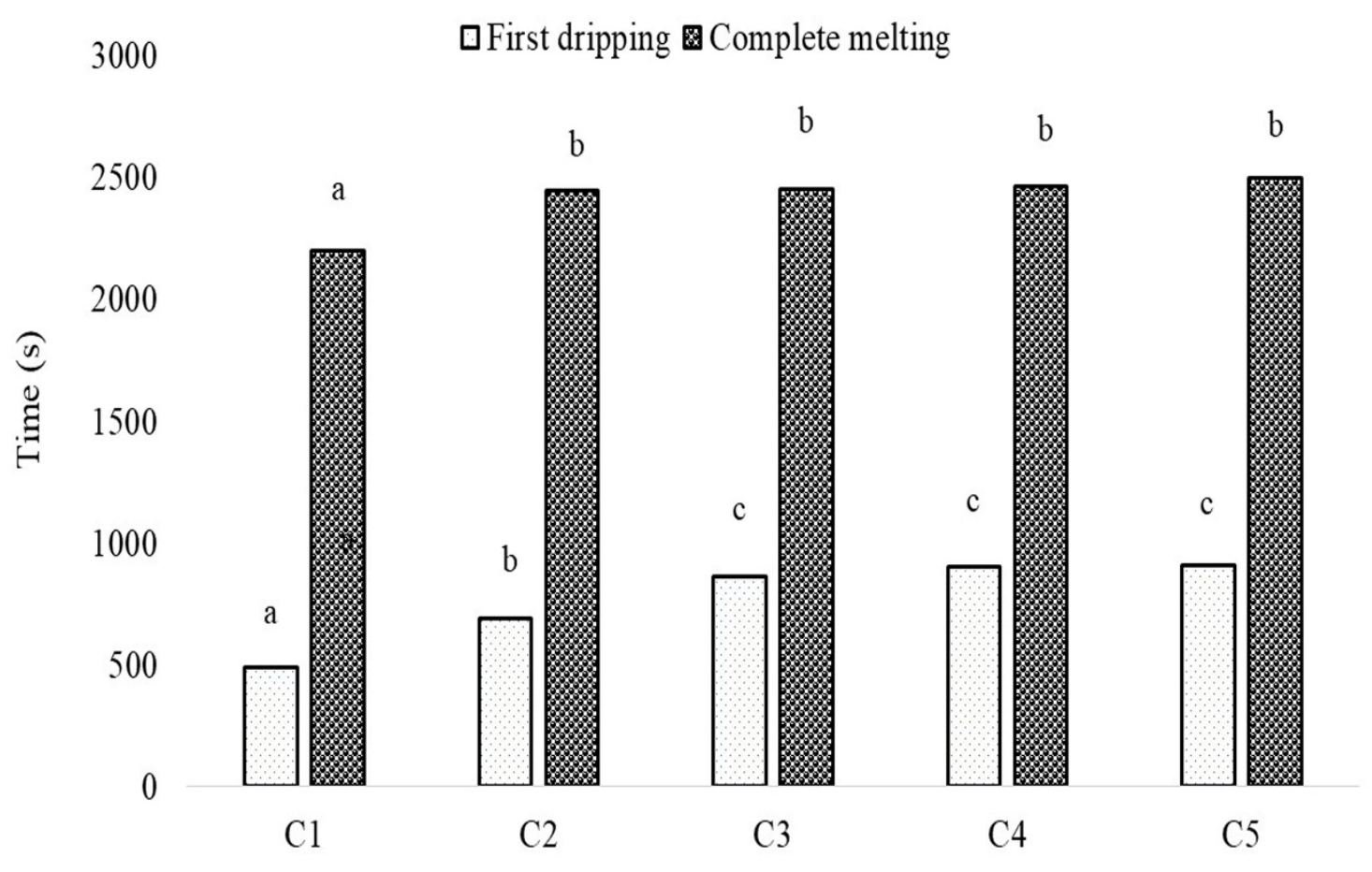

Figure 6. First dripping and complete melting times of ice cream samples. Different letters above the bars indicate significant differences by Duncan multiple range test $(\mathrm{p}<0.05)$.

The consistency of the mixture, the components that form the mixture, and the structures of the ice crystals also affect the melting rate in the ice cream samples (Javidi et al., 2016). Balthazar et al. (2017) reported that the corn dietary fibre added ice cream sample got the highest score (1.56) among the other ice cream samples in their research in which they studied the melting rates of the ice cream samples that they produced using sheep milk fat, fructo-oligosaccharide, resistant starch, short chain fructo-oligosaccharide, galactooligosaccharide, inulin, corn dietary fibre, and polydextrose components. Because dietary fibres have high water binding capacity, they contribute positively to the textural properties of ice creams (Dervişoğlu and Yazıcı, 2006). It is thought that dietary fibre that fruits contain has a role in rising of the first drop and complete melting times depending on the addition of fruits. Also, Muse and Hartel (2004) reported that hardness of ice cream was related to ice phase volume, size of ice crystals, and increased in volume, fat stabilization, and rheological properties of the mixture. 


\subsection{Sensory attributes}

The sensory analysis scores of the ice creams are presented in Table 5 and adding Kavilca fibre into the ice creams significantly affected $(p<0.01)$ the sensory scores. The colour value of the control sample got the lowest value, whereas the colour values of the samples $\mathrm{C} 4$ and $\mathrm{C} 5$ got the highest score. It was detected that the sample C5 had the highest scores in terms of taste and aroma (6.90), resistance to melting (7.20), icy structure (6.70), and colour (7.50). The fact that
Karaca et al. (2009) detected that the ice cream samples they produced using carbohydratebased fat substitutes got lower scores than the control sample in terms of flavour scores shows that the result of their study is not parallel to the results of our study. Because, we can see in Table 5 that Kavilca fibre does not affect the taste and aroma of the samples negatively, and even it improves them.

Table 5. The effect of different Kavilca fiber concentrations on sensory properties of ice creams

\begin{tabular}{|c|c|c|c|c|c|}
\hline \multirow{2}{*}{ Sensory parameters } & \multicolumn{5}{|c|}{ Samples } \\
\cline { 2 - 6 } & C1 & C2 & C3 & C4 & C5 \\
\hline Color & $6.9 \pm 1.49^{\mathrm{a}}$ & $7.35 \pm 1.57^{\mathrm{a}}$ & $7.30 \pm 1.72^{\mathrm{a}}$ & $7.50 \pm 1.70^{\mathrm{a}}$ & $7.50 \pm 1.64^{\mathrm{a}}$ \\
\hline Body and texture & $6.60 \pm 1.41^{\mathrm{a}}$ & $7 \pm 1.39^{\mathrm{ab}}$ & $6.95 \pm 1.44^{\mathrm{ab}}$ & $7.45 \pm 1.5^{\mathrm{b}}$ & $6.75 \pm 1.49^{\mathrm{ab}}$ \\
\hline Resistant to melting & $6.75 \pm 2.07^{\mathrm{a}}$ & $6.55 \pm 1.79^{\mathrm{a}}$ & $6.85 \pm 2.20^{\mathrm{a}}$ & $7.15 \pm 1.57^{\mathrm{a}}$ & $7.20 \pm 1.38^{\mathrm{a}}$ \\
\hline Taste and Aroma & $5.6 \pm 2.34^{\mathrm{a}}$ & $5.40 \pm 1.95^{\mathrm{a}}$ & $6.30 \pm 2.30^{\mathrm{ab}}$ & $6.75 \pm 2.07^{\mathrm{b}}$ & $6.90 \pm 1.94^{\mathrm{b}}$ \\
\hline Creaminess & $5.60 \pm 2.25^{\mathrm{ab}}$ & $5.15 \pm 2.27^{\mathrm{a}}$ & $5.80 \pm 2.45^{\mathrm{ab}}$ & $6.40 \pm 1.58^{\mathrm{b}}$ & $6.10 \pm 1.97^{\mathrm{ab}}$ \\
\hline Mouth feeling & $6.30 \pm 2.28^{\mathrm{ab}}$ & $6.10 \pm 2.43^{\mathrm{a}}$ & $6.95 \pm 2.18^{\mathrm{ab}}$ & $7.15 \pm 1.54^{\mathrm{b}}$ & $6.65 \pm 1.84^{\mathrm{ab}}$ \\
\hline Gumming structure & $6.55 \pm 2.13^{\mathrm{a}}$ & $6.10 \pm 2.04^{\mathrm{a}}$ & $6.40 \pm 2.10^{\mathrm{a}}$ & $6.95 \pm 1.90^{\mathrm{a}}$ & $6.45 \pm 2.13^{\mathrm{a}}$ \\
\hline Iced structure & $5.75 \pm 2.57^{\mathrm{ab}}$ & $5.15 \pm 2.54^{\mathrm{a}}$ & $5.80 \pm 2.18^{\mathrm{b}}$ & $6.50 \pm 1.90^{\mathrm{ab}}$ & $6.70 \pm 2.24^{\mathrm{b}}$ \\
\hline General acceptability & $5.55 \pm 1.90^{\mathrm{a}}$ & $6.05 \pm 2.01^{\mathrm{ab}}$ & $6.60 \pm 1.93^{\mathrm{bc}}$ & $7.25 \pm 1.53^{\mathrm{c}}$ & $6.75 \pm 1.89^{\mathrm{bc}}$ \\
\hline
\end{tabular}

C1, control (without KF); C2, 0.5\% (w/w) KF added; C3, 1\% (w/w) KF added; C4, 1.5\% (w/w) KF added and $\mathrm{C} 5,2 \%(\mathrm{w} / \mathrm{w}) \mathrm{KF}$ added. *Means within the same row with different letters are significantly different $(\mathrm{p}<0.05)$.

Güven et al. (2003) detected that the structure and texture scores of the Kahramanmaraş ice cream samples they produced using different stabilizers were between 3.50-4.58 and it was seen that the structure and texture scores that the researchers found were lower than the results of our study. It was determined that the samples were ranked from the most liked to the least liked as $\mathrm{C} 4, \mathrm{C} 5$, C3, C2, and C1, respectively. Crizel et al. (2014) reported that the ice cream samples they produced using orange fibre were affected by the fibre negatively in terms of flavour and aroma. However, when we look at their overall acceptability scores, the samples that were produced by using $1.5 \%$ orange fibre got higher 
scores. Also, when we look at the ice creams produced by adding different ingredients, it was reported that overall acceptability scores of the ice creams that were produced using $10 \%$ soy milk was higher when compared with the ones produced using $20 \%$ and $30 \%$ concentrations and they were liked more (David, 2016); Yüksel et al. (2015b) reported that the ice cream that was produced with $1 \%$ concentration got the highest score (7.69) among the ice cream samples produced by using turpentine coffee; Dervişoğlu and Yazıcı (2001) reported that the panelists liked the samples containing $0.75 \%$ cola extract, $15 \% \mathrm{Na}_{2} \mathrm{CO}_{3}$ and $0.1 \%$ cola aroma the most among the ice cream samples that they produced using cola extract and flavour; and Goraya and Bajwa (2015) reported that the ice cream samples with $10 \%$ concentration were liked more among the ice cream samples they produced using a special grape type of India called Indian gooseberry (or amla). These findings show that consumers are open to diversity in ice cream production. Sensory evaluation of the effects of preparing functional products on diversity is very important.

\section{Conclusions}

In this study, it was determined that Kavilca fibre addition has affected some of the physicochemical properties (dry matter, ash, acidity, $\mathrm{pH}$, and fat) of the ice cream samples. When especially the fat ratio was evaluated, the fact that the fat ratios of the ice cream samples decreased depending on an increased in the fibre concentration revealed the importance of fibre once again in terms of preventing many chronic diseases. Because dietary fibres are used as fat substitutes in reducing the fat content of ice creams. It was detected that there were significant structural variations between the control sample and the samples containing Kavilca fibre in the SEM images of the ice cream samples. It was detected that a protein network of the control sample consisted of serum phase and gaps in which air cells exist, there were filamentous extensions that surrounded protein networks in the samples in which Kavilca fibre was added, the numbers of serum phase and air gaps decreased and their diameters diminished. It was observed that filamentous structures increased, a denser protein network was formed and the structure was harder parallel to the increased in fibre concentration. Regarding the sensory properties, the effect of fibre addition on colour, structure and texture, resistance to melting, flavour and aroma, cream taste, melting in mouth, gummy structure, icy structure, foreign flavour, overall acceptability and fibre structure was found to be important. In conclusion, it was detected that fibre addition contribute positively to the chemical, physical, and sensory properties of ice creams and thus Kavilca fibre can be used in food products.

\section{References}

AACC. (1995). Approved methods of the AACC (methods 10-09) (9thed.) St. Paul, $\mathrm{MN}$ : American Association of Cereal Chemists.

AACC International. (2009). Approved methods of analysis. Method 56-10.02, 44-40.01, 3240.01, 32-07.01 (11th Ed.). St. Paul, MN, U.S.A: AACC International.

Akbari, M., Eskandari, M. H., Niakosari, M., Bedeltavana, A., (2016). The effect of inulin on the physicochemical properties and sensory attributes of low-fat ice cream. International Dairy Journal, 57, 5255.

Akalın, A. S., Ünal, G., Dinkçi, N., Hayaloğlu, A. A., (2012). Microstructural, textural, and sensory characteristics of probiotic yogurts fortified with sodium calcium caseinate or whey protein concentrate. Journal of Dairy Science, 95(7), 3617-3628.

Akalın, A. S., Kesenkaş, H., Dinkçi, N., Ünal, G., Özer, E., Kınık, O., (2018). Enrichment of probiotic ice cream with different dietary fibres: Structural characteristics and culture viability. Journal of Dairy Science, 101(1), 37-46.

Akın, M. B., Akın, M. S., Kırmacı, Z., (2007). Effects of inulin and sugar levels on the 
viability of yoğurt and probiotic bacteria and the physical and sensory characteristics in probiotic ice-cream. Food Chemistry, 104, 93-9.

Alan, P. A., Ofelia, R. S., Patricia, T., Rosario, Maribel, R. S., (2012). Cereal bran and wholegrain as a source of dietary fibre: technological and health aspects. International Journal of Food Sciences and Nutrition, 63(7), 882-892.

Balthazar, C. F., Silva, H. A., Vieira, A. H., Neto, R. P. C., Cappato, L. P., Coimbra, P. T., ... Freitas, M. Q., (2017). Assessing the effects of different prebiotic dietary oligosaccharides in sheep milk ice cream. Food Research International, 91, 38-46.

Bauer, J. L., Harbaum-Piayda, B., Schwarz, K., (2012). Phenolic compounds from hydrolyzed and extractedfibre-rich byproducts. Food Science and Technology, 47, 246-254.

Bilgiçli, N., (2009). Effect of buckwheat flour on cooking quality and some chemical, antinutritional and sensory properties of erişte, Turkish noodle. International Journal of Food Sciences and Nutrition, 60(4), 7080.

Blond, G., (1994). Mechanical properties of frozen model solutions. In Water in Foods (pp. 253-269).

Ciclitira, P. J., Ellis, H. J., Lundin, K. E. A., (2005). Gluten-free diet-what is toxic? Practice \& Researh Clinical Gastroenterology, 19(3), 359-371

Crizel, T. D. M., Araujo, R. R. D., Rios, A. D. O., Rech, R., Flôres, S. H., (2014). Orange fibre as a novel fat replacer in lemon ice cream. Food Science and Technology, 34(2), 332-340.

Çakmakçı, S., Topdaş, E. F., Kalın, P., Han, H., Şekerci, P. P., Köse, L., Gülçin, İ., (2015). Antioxidant capacity and functionality of oleaster (Elaeagnus angustifolia L.) flour and crust in a new kind of fruity ice cream. International Journal of Food Science and Technology, 50(2), 472-481.
David, J., (2016). Studies on organoleptic attributes and cost analysis of soy icecream. Research Journal of Animal Husbandry and Dairy Science, 7(1), 7-10.

Dervişoğlu, M., Yazıcı, F., (2001). Production of Ice Cream with Cola Extract. Turkish Journal of Agriculture and Forestry, 25(4), 283-289.

Dervişoğlu, M., Yazıcı, F., (2006). The effect of citrus fibre on the physical, chemical and sensory properties of ice cream. Food Science and Technology International, 12(2), 159-164.

Dizlek, H., Özer, M. S., İnanç, E., Gül, H. (2009). Composition of Buckwheat (Fagopyrum Esculentum Moench) and Its Possible Uses in Food Industry. Journal of Food, 34(5).

Goraya, R. K., Bajwa, U., (2015). Enhancing the functional properties and nutritional quality of ice cream with processed amla (Indian gooseberry). Journal of Food Science and Technology, 52(12), 7861-7871.

Güven, M., Karaca, O. B., (2002). The effects of varying sugar content and fruit concentration on the physical properties of vanilla and fruit ice cream type frozen yogurts. International Journal of Food Sciences and Nutrition, 55, 27-31.

Güven, M., Karaca, O. B., Kaçar, A., (2003). The effects of the combined use of stabilizers containing locust bean gum and of the storage time on Kahramanmaraş type ice creams. International Journal of Dairy Technology, 56(4), 223-228.

Hayıt, F., Gül, H., (2005). The importance in terms of health of buckwheat and use in bakery. Journal of Agricultural Faculty of Uludag University, 29(1), 123-131.

IBM corp. (2013). Released 2013. IBM SPSS Statistics for Windows.

Javidi, F., Razavi, S. M., Behrouzian, F., Alghooneh, A., (2016). The influence of basil seed gum, guar gum and their blend on the rheological, physical and sensory properties of low fat ice cream. Food Hydrocolloids, 52, 625-633. 
Karaca, O. B., Güven, M., Yaşar, K., Kaya, S., Kahyaoğlu, T., (2009). The functional, rheological and sensory characteristics of ice creams with various fat replacers. International Journal of Dairy Technology, 62(1), 93-99.

Kurt, A., Çakmakçı, S., Çağlar, A., (2007). Süt ve Mamulleri Muayene ve Analiz Metotları Rehberi.

Lawless, H. T., Heymann, H., (2010). Sensory evaluation of food: principles and practices. Springer Science \& Business Media.

Marshall, R. T., Goff, H. D., Hartel, R. W., (2003). Ice cream, (3rd ed.), Aspen Publishers, New York.

Marshall, R. T., Arbuckle, W. S., (1996). Ice cream 5th edition. Chapman and Hull, New York.

Muse, M. R., Hartel, R. W., (2004). Ice cream structural elements that affect melting rate and hardness. Journal of Dairy Science, 87(1), 1-10.

Parussolo, G., Busatto, R. T., Schmitt, J., Pauletto, R., Schons, P. F., Ries, E. F., (2017). Synbiotic ice cream containing yacon flour and Lactobacillus acidophylus NCFM. LWT-Food Science and Technology, 82, 192-198.

Prosky, L., Asp, N. G., Scheweizer, T. F., DeVries, J. W., Furda, I., (1988). Determination of insoluble and soluble, and total dietary fibre in foods and food products: Interlaboratory study. Journal of the Association of Official Analytical Chemists, 71, 1017-1023.

Ramirez-Santiago, C., Ramos-Solis, L., LobatoCalleros, C., Peña-Valdivia, C., VernonCarter, E. J., Alvarez-Ramírez, J., (2010). Enrichment of stirred yogurt with soluble dietary fibre from Pachyrhizus erosus L. Urban: Effect on syneresis, microstructure and rheological properties. Journal of Food Engineering, 101(3), 229-235.

Rodehutscord, M., Rückert, C., Maurer, H. P., Schenkel, H., Schipprack, W., Bach Knudsen, K. E., Schollenberger, M., Schollenberger, M., Eklund, M., Siegert,
W., Mosenthin, R., (2016). Variation in chemical composition and physical characteristics of cereal grains from different genotypes. Archives of Animal Nutrition, 70(2), 87-107.

Sánchez-Alonso, I., Haji-Maleki, R., Borderías, A. J., (2006). Effect of wheat fibre in frozen stored fish muscular gels. European Food Research and Technology, 223(4), 571-576. Sandoval-Castilla, O., Lobato-Calleros, C., Aguirre-Mandujano, E., Vernon-Carter, E. J., (2004). Microstructure and texture of yogurt as influenced by fat replacers. International Journal, 14(2), 151-159.

Soukoulis, C., Panagiotidis, P., Koureli, R., Tzia, C., (2007). Industrial yogurt manufacture: Monitoring of fermentation process and improvement of final product quality. Journal Dairy Science, 90, 26412654.

Soukoulis, C., Lebesi, D., Tzia, C., (2009). Enrichment of ice cream with dietary fibre: Effects on rheological properties, ice crystallisation and glass transition phenomena. Food Chemistry, 115, 665-671.

Torbica, A., Hadnađev, M., Dapčević, T., (2010). Rheological, textural and sensory properties of glutenfree bread formulations based on rice and buckwheat flour. Food Hydrocolloids, 24(6), 626-632.

Türksoy, S., Özkaya, B., (2006). Gluten ve Çölyak hastalığı. Türkiye, 9, 24-26.

Urgancı, N., (2005). Çölyak hastalarına ekmek zehir oluyor. http://212.174.46.149/w/ dergi/basinpdf/kasim2004/18_19_20.pdf 5.

Vyncke, W., (1981). $\mathrm{pH}$ of fish muscle comparison of methods. Copenhagen, Denmark: Western European Fish Technologists' Association (WEFTA).1030A. Rodriguez-Casado et al. / Food Chemistry, 103(2007), 1024-1030.

Yanglar, F., (2015a). Mineral contents and physical, chemical, sensory properties of ice cream enriched with date fibre. Italian Journal of Food Science, 27(3), 397-406. 
Yangilar, F., (2015b). Effects of green banana flour on the physical, chemical and sensory properties of ice cream. Food Technology and Biotechnology, 53(3), 315.

Y1lmaz, I., (2005). Physicochemical and sensory characteristics of low-fat meatballs with added wheat bran. Journal of Food Engineering, 69, 369-373.

Yüksel, A. K., (2015a). The Effects of Blackthorn (Prunus spinosa L.) Addition on Certain Quality Characteristics of Ice Cream. Journal of Food Quality, 38(6), 413421.

Yüksel, A. K., Şat, I. G., Yüksel, M., (2015b). The effect of terebinth (Pistacia terebinthus L.) coffee addition on the chemical and physical characteristics, colour values, organic acid profiles, mineral compositions and sensory properties of ice creams. Journal of Food Science and Technology, 52(12), 8023-8031.

Zhao, H. M., Guo, X. N., Zhu, K. X., (2017). Impact of solid state fermentation on nutritional, physical and flavour properties of wheat bran. Food Chemistry, 217, 28-36.

\section{Acknowledgments}

The researchers are grateful to the Erzincan University Research Fund (Erzincan, Turkey) for financial support (Project No: FBA-2017376) 